\title{
Effects of Thickness and Ignition Location on Flame Spread Rates in Furniture Calorimeter Tests of Polyurethane Foam
}

\author{
LUKE ROBSON, DAVID TORVI \\ Department of Mechanical Engineering \\ University of Saskatchewan \\ Saskatoon, SK Canada \\ MATTHEW OBACH, ELIZABETH WECKMAN \\ Department of Mechanical and Mechatronics Engineering \\ University of Waterloo \\ Waterloo, ON Canada
}

\begin{abstract}
Furniture calorimeter tests of polyurethane foam specimens were conducted to determine the effects of ignition location and specimen thickness on measured flame spread rates. These measurements were made using a new procedure that measured flame areas using infrared video records. Furniture calorimeter tests were conducted using specimens with thicknesses ranging between $2.5 \mathrm{~cm}$ and $10 \mathrm{~cm}$, which were ignited in either the centre or on one edge. Flame spread rates increased with foam thickness, and flame spread rates in centre ignition tests were quicker than in edge ignition tests. These flame spread measurements will be used in a model, along with heat release rate data from cone calorimeter tests of the same foam, in order to predict heat release rates in furniture calorimeter tests of polyurethane foam slabs.
\end{abstract}

KEYWORDS: heat release rate, flame spread, fire growth, furniture calorimeter, polyurethane foam

\section{INTRODUCTION}

Polyurethane foam is used extensively in mattresses and furnishings. Understanding the fire behaviour of these products is very important, as these items are found throughout the home, and if ignited, they represent a significant danger due to their rate of heat release, as well as the total energy released as they burn. This danger is evident in the relatively large number of people who are killed or injured each year in fires that began when mattresses or pieces of furniture were ignited [1]. Therefore, industry, regulators and the fire service are very interested in developing methods that can evaluate the fire performance of complete products and their components.

There are a number of standard tests for slab foam products, which use the cone (e.g., ASTM E 1474 [2]) or furniture calorimeter (e.g., CFR 1633 [3], CAN/ULC-S137-07 [4]). As full-scale testing is relatively expensive, and there are a small number of full-scale testing facilities available, there is an interest in developing models that can be used to predict the results of full-scale tests based on small-scale test results. For example, such scaling models could be used during the design process to predict, in a cost-effective manner, how a change in the properties of the foam, such as thickness and density, might impact the fire performance of the finished product.

One of the scaling models that has used in the past was developed during the Combustion Behaviour of Upholstered Furniture (CBUF) project in Europe in the 1990's [5]. This model uses heat release rate density measurements made in the cone calorimeter $\left(q^{\prime \prime}(t)\right)$, along with a time dependent flame area $\left(A_{f}(t)\right)$, to predict the full-scale heat release rate $(Q(t))$ using the following equation:

$Q(t)=\int_{0}^{t} q^{\prime \prime}(t-\tau) \frac{d A_{f}(\tau)}{d \tau} d \tau$

where $\tau$ is a dummy variable. The model is based on the assumption that the heat release rate versus time curve for each $10 \mathrm{~cm}$ by $10 \mathrm{~cm}$ portion of the full-scale specimen will be the same as the heat release rate versus time curve for a $10 \mathrm{~cm}$ by $10 \mathrm{~cm}$ specimen of the same material tested in the cone calorimeter.

While a number of detailed models of foam combustion have been described recently in the literature 
(e.g., [6-9]), these models require a significant amount of input data in order to predict chemical kinetics, heat transfer and other phenomena that take place during the burning of the foam. This data may be difficult to obtain for design or regulatory purposes, especially as overall designs of products and individual components are modified on a regular basis. Changes to chemical composition of polyurethane foam and other components will also affect fire performance [10-11]. The more generalized CBUF model was chosen for evaluation purposes in this research as it would allow users to predict full-scale test results using results from a standard small-scale test of a representative sample of the full-scale product.

Previous research by the UofS and UW groups has demonstrated the effects of thickness, density, and ignition location on heat release rate from polyurethane foam slabs [12-14]. In addition, they have been evaluating the ability of the CBUF model to predict furniture calorimeter test results of polyurethane foam slabs $[15,16]$. To this end, heat release rate density measurements were made during cone calorimeter tests, and flame area measurements were made during furniture calorimeter tests.

In the course of this research, a method for measuring flame areas using image analysis of infrared video records of full-scale tests was developed [16]. This method is an improvement over previous methods in which a user had to determine the flame area manually from photographs or video record of a test [17]. This paper is focussed on discussion of the measurement technique itself as applied to a study of the effects of foam thickness and ignition location on flame spread rate measurements in the furniture calorimeter. The flame spread rate measurements are then combined with cone calorimeter heat release rate density measurements, and used to evaluate the ability of the CBUF model to predict full-scale heat release rate measurements [16]. If such scaling models can successfully predict full-scale heat release rates for polyurethane foam slabs, their ability to predict the more complex cases of full-scale fire behaviour of solid-core and inner-spring mattresses, and upholstered furniture, can then be evaluated.

\section{MATERIALS AND METHODS}

Polyurethane foam samples were obtained from several branches of a Canadian retail chain in KitchenerWaterloo and Saskatoon between July, 2006 and June, 2010. These foams are considerably less dense than foams typically found in solid-core mattresses and furniture, as they are mainly intended to be used as camping pads. No detailed information was available on the base chemical composition of the foam. However, as the foam could be quickly and repeatably ignited using a small ignition source, resulting in self-propagating fires that consumed practically the entire specimen, the samples did not appear to contain a fire retardant. The foams were sold in rolls with nominal dimensions of $0.5 \mathrm{~m}$ by $1.4 \mathrm{~m}$ by $2.5 \mathrm{~cm}$ thick, $0.6 \mathrm{~m}$ by $1.8 \mathrm{~m}$ by $5.0 \mathrm{~cm}$ thick, $0.6 \mathrm{~m}$ by $1.8 \mathrm{~m}$ by $7.5 \mathrm{~cm}$ thick, and $1.2 \mathrm{~m}$ by $1.8 \mathrm{~m}$ by $10 \mathrm{~cm}$ thick. Cone calorimeter tests demonstrate that combustion of this foam occurs in two stages. First the structure of the foam collapses, and then when the foam has melted it burns as a liquid pool fire [16].

The foam was allowed to expand and flatten after the rolls were unwrapped. It was then cut into individual test specimens with nominal dimensions of $0.6 \mathrm{~m}$ by $0.6 \mathrm{~m}, 0.6 \mathrm{~m}$ by $1.2 \mathrm{~m}$ or $1.2 \mathrm{~m}$ by $1.2 \mathrm{~m}$. Dimensions of individual test specimens are given in Tables 1 and 2, along with the dates of testing and conditions in the laboratory. The average density of the individual test specimens was $17.0 \mathrm{~kg} / \mathrm{m}^{3}$ with a standard deviation of $1.4 \mathrm{~kg} / \mathrm{m}^{3}$, and a range of 15.9 to $19.3 \mathrm{~kg} / \mathrm{m}^{3}$. The main reason for the variation in density was that the foams were tightly wrapped in their packaging and some pieces did not expand as much as others. As the foams were purchased over a relatively long period of time, it is also expected that the composition of individual foam specimens may not be exactly the same. Aging effects may also be important.

Testing was conducted in the main burn hall at the University of Waterloo Live Fire Research Facility. Specimens were conditioned for at least 24 hours in various rooms within the facility prior to testing. Temperatures and relative humidity in the rooms used for conditioning of test specimens in this study were between 22 and $23^{\circ} \mathrm{C}$, and 32 and $67 \%$ respectively during the test period. Conditions in these rooms were loosely controlled using an air handling system. A dehumidifier was also run during the day, if necessary. However, this dehumidifier was not run during evenings or the weekend.

The temperature and relative humidity in the main burn hall of the facility were not controlled, as the facility has large open fan dampers and a large door which is often open to the outside. Therefore, as shown in Tables 1 and 2, there were significant variations in the environmental conditions during the testing period. The humidity ratio of the air in the laboratory ranged between a low of $0.004 \mathrm{~kg}$ of water vapour per kg dry air to a high of $0.015 \mathrm{~kg}$ of water vapour per kg dry air. 
Table 1. Test Specimens and Environmental Conditions (Centre Ignition Location).

\begin{tabular}{|c|c|c|c|c|c|}
\hline \multirow{2}{*}{$\begin{array}{c}\text { Test } \\
\text { Specimen }\end{array}$} & \multirow{2}{*}{$\begin{array}{c}\text { Test Date } \\
\text { (temperature \& relative } \\
\text { humidity) }\end{array}$} & \multicolumn{3}{|c|}{ Dimensions (cm) } & \multirow{2}{*}{$\begin{array}{c}\text { Mass } \\
(\mathbf{k g})\end{array}$} \\
\hline & & Width & Length & Thickness & \\
\hline $\mathrm{C} 1-1^{\mathrm{a}}$ & $\begin{array}{c}\text { July } 19,2010 \\
\left(26^{\circ} \mathrm{C}, 56 \%\right) \\
\end{array}$ & 61 & 52 & 2.5 & 0.13 \\
\hline $\mathrm{C} 1-2$ & $\begin{array}{l}\text { July } 20,2010 \\
\left(25^{\circ} \mathrm{C}, 56 \%\right)\end{array}$ & 61 & 53 & 2.5 & 0.13 \\
\hline $\mathrm{C} 1-3$ & $\begin{array}{c}\text { July } 20,2010 \\
\left(29^{\circ} \mathrm{C}, 43 \%\right)\end{array}$ & 61 & 53 & 2.5 & 0.14 \\
\hline $\mathrm{C} 1-4$ & $\begin{array}{c}\text { July } 21,2010 \\
\left(27^{\circ} \mathrm{C}, 60 \%\right)\end{array}$ & 61 & 52 & 2.5 & 0.14 \\
\hline $\mathrm{C} 2-1$ & $\begin{array}{c}\text { July } 19,2010 \\
\left(26^{\circ} \mathrm{C}, 54 \%\right)\end{array}$ & 61 & 63 & 5.0 & 0.31 \\
\hline $\mathrm{C} 2-2$ & $\begin{array}{c}\text { July } 20,2010 \\
\left(28^{\circ} \mathrm{C}, 43 \%\right) \\
\end{array}$ & 61 & 62 & 5.0 & 0.32 \\
\hline $\mathrm{C} 2-3$ & $\begin{array}{c}\text { July } 21,2010 \\
\left(27^{\circ} \mathrm{C}, 59 \%\right)\end{array}$ & 61 & 63 & 5.0 & 0.31 \\
\hline $\mathrm{C} 3-1$ & $\begin{array}{l}\text { July } 20,2010 \\
\left(24^{\circ} \mathrm{C}, 66 \%\right)\end{array}$ & 62 & 61 & 7.5 & 0.50 \\
\hline C3-2 & $\begin{array}{c}\text { July } 20,2010 \\
\left(29^{\circ} \mathrm{C}, 40 \%\right)\end{array}$ & 61 & 62 & 7.5 & 0.47 \\
\hline $\mathrm{C} 3-3$ & $\begin{array}{c}\text { July } 21,2010 \\
\left(28^{\circ} \mathrm{C}, 56 \%\right)\end{array}$ & 62 & 61 & 7.5 & 0.47 \\
\hline $\mathrm{C} 4-1$ & $\begin{array}{c}\text { May } 15,2008 \\
\left(17^{\circ} \mathrm{C}, 38 \%\right)\end{array}$ & 60 & 62 & 9.3 & 0.58 \\
\hline $\mathrm{C} 4-2$ & $\begin{array}{c}\text { May } 15,2008 \\
\left(18^{\circ} \mathrm{C}, 36 \%\right)\end{array}$ & 60 & 62 & 9.5 & 0.58 \\
\hline $\mathrm{C} 4-3$ & $\begin{array}{c}\text { July } 21,2010 \\
\left(28^{\circ} \mathrm{C}, 53 \%\right)\end{array}$ & 59 & 61 & 9.3 & 0.58 \\
\hline CC4-1 & $\begin{array}{c}\text { May } 16,2008 \\
\left(18^{\circ} \mathrm{C}, 36 \%\right) \\
\end{array}$ & 121 & 124 & 9.7 & 2.31 \\
\hline $\mathrm{CC} 4-2$ & $\begin{array}{c}\text { July } 22,2010 \\
\left(25^{\circ} \mathrm{C}, 59 \%\right)\end{array}$ & 122 & 124 & 9.8 & 2.53 \\
\hline $\mathrm{CC} 4-3$ & $\begin{array}{c}\text { July } 21,2010 \\
\left(28^{\circ} \mathrm{C}, 50 \%\right)\end{array}$ & 125 & 122 & 9.3 & 2.35 \\
\hline
\end{tabular}

${ }^{\mathrm{a}}$ Flame spread measurements are not available for test $\mathrm{C} 1-1$

Specimens were placed on top of an electronic load cell that was covered with a ceramic protective sheet, cement board and tinfoil sheets (Fig. 1). The entire assembly was placed on fire bricks under the furniture calorimeter hood. In the 2008 tests, the test specimens were ignited using a small hand-held propane torch, while in the 2009 and 2010 tests a butane barbeque lighter was used. It was estimated via cone calorimeter testing that the heat release rate of the propane torch is $1.3 \mathrm{~kW}$ and the butane barbeque lighter is $0.1 \mathrm{~kW}$, both of which are much less than $10 \mathrm{~kW}$ and the resolution limit on the furniture calorimeter. After ignition, standard test procedures for large-scale oxygen consumption calorimetry were followed.

Two ignition locations were used for testing. For centre ignition tests, a $6.4 \mathrm{~cm}$ diameter hole with a depth of $1.3 \mathrm{~cm}$ was cut at the centre of the specimen to ensure a consistent ignition location for each test (Fig. 2). The ignition source was positioned at this location. For edge ignition, the ignition source was placed on a mark on the top surface of the specimen at the midway point along the width (Fig. 3). 
Table 2. Test Specimens and Environmental Conditions (Edge Ignition Location).

\begin{tabular}{|c|c|c|c|c|c|}
\hline \multirow{2}{*}{$\begin{array}{c}\text { Test } \\
\text { Specimen }\end{array}$} & \multirow{2}{*}{$\begin{array}{c}\text { Test Date } \\
\text { (temperature } \& \text { relative } \\
\text { humidity) }\end{array}$} & \multicolumn{3}{|c|}{ Dimensions (cm) } & \multirow{2}{*}{$\begin{array}{c}\text { Mass } \\
(\mathbf{k g})\end{array}$} \\
\hline & & Width & Length & Thickness & \\
\hline E1-1 & $\begin{array}{c}\text { June } 18,2009 \\
\left(16^{\circ} \mathrm{C}, 90 \%\right)\end{array}$ & 51 & 142 & 2.5 & 0.35 \\
\hline E1-2 & $\begin{array}{c}\text { June } 18,2009 \\
\left(16^{\circ} \mathrm{C}, 90 \%\right)\end{array}$ & 52 & 142 & 2.5 & 0.30 \\
\hline E1-3 & $\begin{array}{c}\text { June } 18,2009 \\
\left(16^{\circ} \mathrm{C}, 90 \%\right)\end{array}$ & 52 & 142 & 2.5 & 0.30 \\
\hline E2-1 & $\begin{array}{c}\text { July } 20,2010 \\
\left(26^{\circ} \mathrm{C}, 49 \%\right)\end{array}$ & 63 & 120 & 5.0 & 0.63 \\
\hline E2-2 & $\begin{array}{l}\text { July } 21,2010 \\
\left(24^{\circ} \mathrm{C}, 82 \%\right)\end{array}$ & 62 & 122 & 5.0 & 0.63 \\
\hline E2-3 & $\begin{array}{c}\text { July } 21,2010 \\
\left(28^{\circ} \mathrm{C}, 53 \%\right)\end{array}$ & 63 & 119 & 5.0 & 0.61 \\
\hline E3-1 & $\begin{array}{c}\text { July } 20,2010 \\
\left(28^{\circ} \mathrm{C}, 44 \%\right)\end{array}$ & 62 & 123 & 7.5 & 1.04 \\
\hline E3-2 & $\begin{array}{c}\text { July } 21,2010 \\
\left(25^{\circ} \mathrm{C}, 75 \%\right)\end{array}$ & 62 & 124 & 7.5 & 0.95 \\
\hline E3-3 & $\begin{array}{c}\text { July } 21,2010 \\
\left(27^{\circ} \mathrm{C}, 53 \%\right)\end{array}$ & 62 & 124 & 7.5 & 0.96 \\
\hline E4-0 & $\begin{array}{c}\text { May } 14,2008 \\
\left(14^{\circ} \mathrm{C}, 72 \%\right)\end{array}$ & 61 & 126 & 10.0 & 1.23 \\
\hline E4-1 & $\begin{array}{c}\text { May } 15,2008 \\
\left(16^{\circ} \mathrm{C}, 41 \%\right)\end{array}$ & 61 & 126 & 9.3 & 1.38 \\
\hline E4-2 & $\begin{array}{l}\text { July } 21,2010 \\
\left(26^{\circ} \mathrm{C}, 68 \%\right)\end{array}$ & 61 & 125 & 9.3 & 1.19 \\
\hline E4-3 & $\begin{array}{c}\text { July } 22,2010 \\
\left(23^{\circ} \mathrm{C}, 69 \%\right)\end{array}$ & 61 & 125 & 9.3 & 1.17 \\
\hline EE4-1 & $\begin{array}{c}\text { May } 15,2008 \\
\left(18^{\circ} \mathrm{C}, 35 \%\right)\end{array}$ & 125 & 122 & 8.8 & 2.76 \\
\hline EE4-2 & $\begin{array}{c}\text { May } 16,2008 \\
\left(14^{\circ} \mathrm{C}, 45 \%\right)\end{array}$ & 125 & 122 & 9.8 & 2.43 \\
\hline EE4-3 & $\begin{array}{c}\text { July } 22,2010 \\
\left(27^{\circ} \mathrm{C}, 54 \%\right)\end{array}$ & 122 & 122 & 9.8 & 2.32 \\
\hline
\end{tabular}

The top surface of each test specimen was marked in a grid pattern of $10 \mathrm{~cm}$ by $10 \mathrm{~cm}$ squares before testing. A FLIR ThermaCAM ${ }^{\circledR}$ S60 infrared (IR) camera (FLIR Systems, Burlington, ON) with a spectral range of 7.5 to $13 \mu \mathrm{m}$, and one or two Sony MiniDV camcorders (Sony of Canada, Toronto, ON) were used to record each of the fire tests. Still photographs were also taken at various times during the test using an Olympus Stylus 770SW (Olympus Canada Inc., Markham, ON) or a Panasonic DMC-LZ10 (Panasonic, Canada, Inc., Mississauga, ON) digital camera. Examples of photographs taken during centre and edge ignition tests are shown in Fig. 2 and 3, respectively. In previous studies, standard or IR video records were used to estimate the flame area as the tests progressed. The researcher would measure the flame area at discrete times in the test, by either measuring the flame area using an IR image, or by adding the number of $10 \mathrm{~cm}$ by $10 \mathrm{~cm}$ squares that were observed to be burning in a standard video image or photograph. While using the IR video records was the more reliable method of estimating the flame areas, this method was still subjective in that the user had to make a decision as to where the limits of the flame area were located in each frame [17]. 


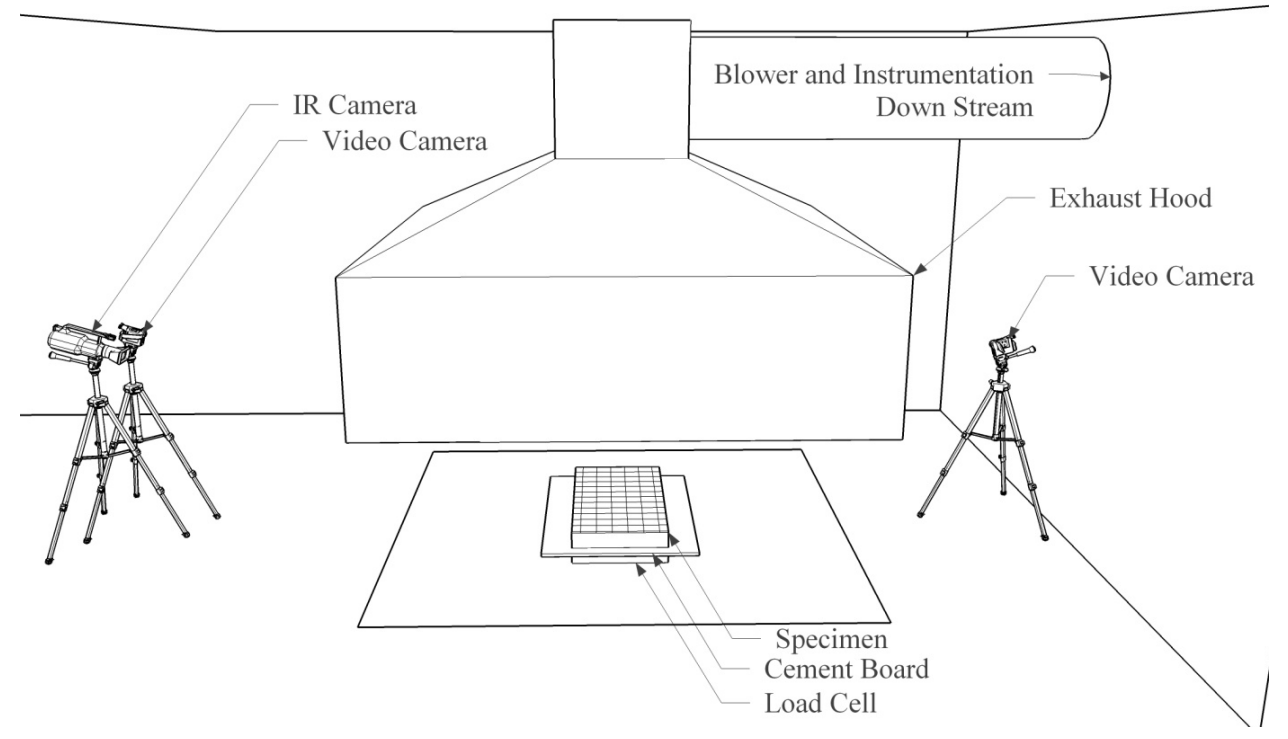

Fig. 1. Furniture Calorimeter Test Set Up, Including Positions of Infrared (IR) and Video Cameras.

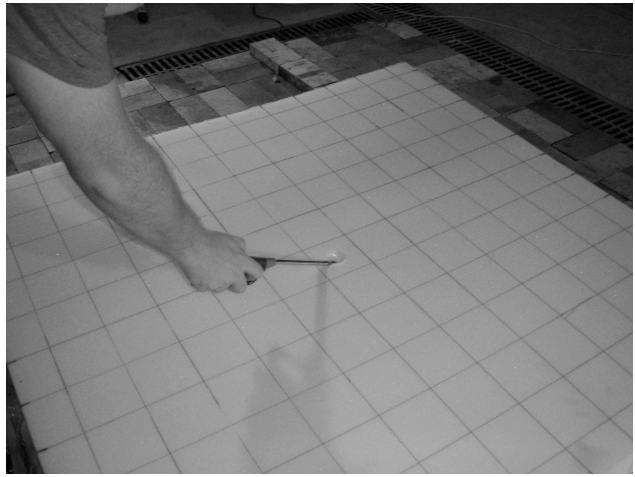

(a) 1 min.

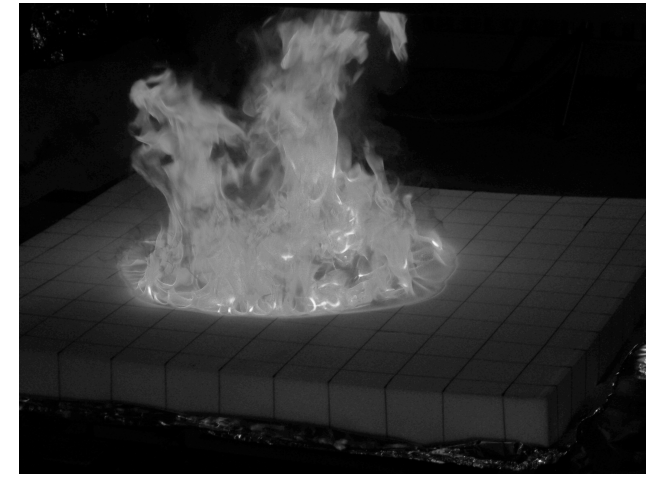

(b) 2 min. after ignition

Fig. 2. Photographs Taken During Test CC4-3.

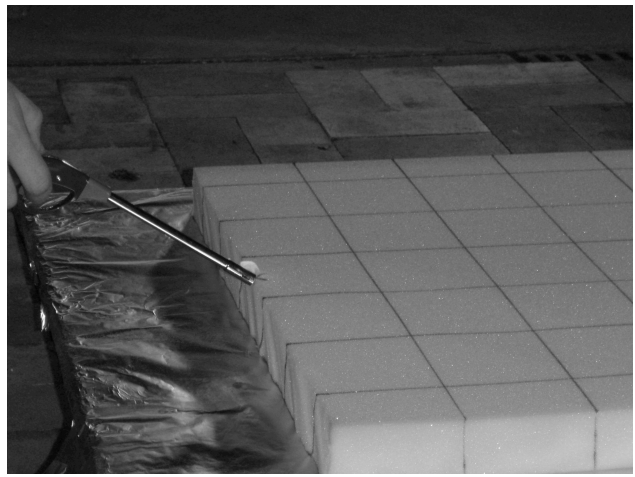

(a) ignition

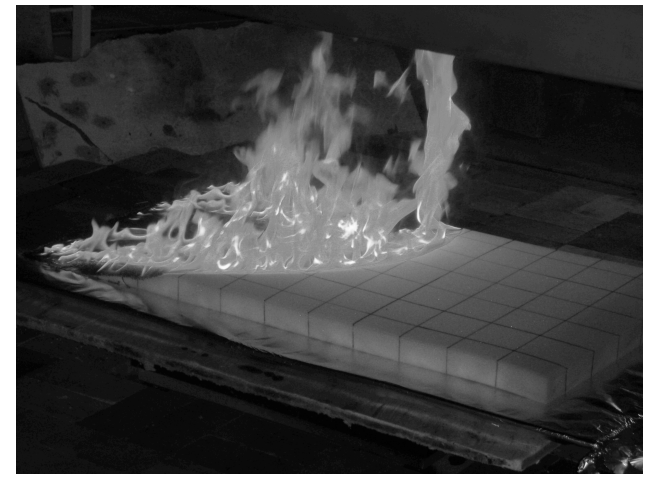

(b) 3 min. after ignition

Fig. 3. Photographs Taken During Test E2-2. 
To determine the flame areas in this research, footage from the IR camera was analyzed using the Image Processing Toolbox in MATLAB ${ }^{\circledR}$ (Mathworks, Inc., Natick, MA). The processing of the IR footage involved five key steps [16]. First a projective transform was used to obtain a "top view" of the specimen in which areas and distances could be directly measured. This was done by first identifying the four corners of the foam specimen and assigning a coordinate system (Fig. 4a). MATLAB ${ }^{\circledR}$ was used to generate a transformation matrix, which was then used to generate the top view (Fig. 4b). Note that the image in Fig. $4 \mathrm{~b}$ appears to be mirrored vertically, due to the coordinate system for image pixel numbering, which results in the origin shown in Fig. 4a being located in the top left corner. One pixel in the transformed image corresponds to an area of $1 \mathrm{~cm}^{2}$ on the actual specimen, which provided a close match to the pixel density in the original image and facilitated use of a simple conversion when measuring distances and areas from the transformed image.

If the back of the specimen was obscured by the plume, an elliptical mask correction was used to remove the plume from the image. It was assumed that the flame front obscured by the plume maintained approximately the same radius of curvature as the rest of the flame front. To apply this correction an elliptical mask was created of approximately the same size as the flaming area, and was placed in such a way as to attenuate the temperature of the plume. The corrected image (Fig. 4c) was then used to measure the flame area at this particular time. While the chemical composition of the polyurethane foam used in these tests is not known, thermal degradation of toluene diisocyanate (TDI) based polyurethane foams generally begins at temperatures ranging from $200^{\circ} \mathrm{C}$ to $300^{\circ} \mathrm{C}$ [18]. It was found that choosing $300^{\circ} \mathrm{C}$ to define the edges of the flame front produced a flame front envelope that closely matched the flame fronts shown in the standard video records of the tests. Therefore, using $300^{\circ} \mathrm{C}$ as the threshold for the flame front, a binary image was created where 0 was assigned to pixels which had temperatures below $300^{\circ} \mathrm{C}$ and 1 was assigned to pixels with temperatures above $300^{\circ} \mathrm{C}$. The flame area at this particular moment in time was then determined using the resulting binary image (Fig. 4d).

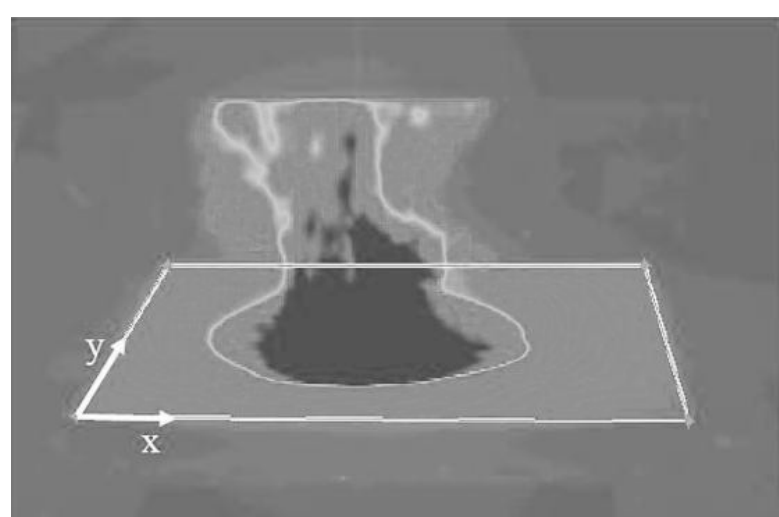

(a) locating corners of foam specimen in IR image

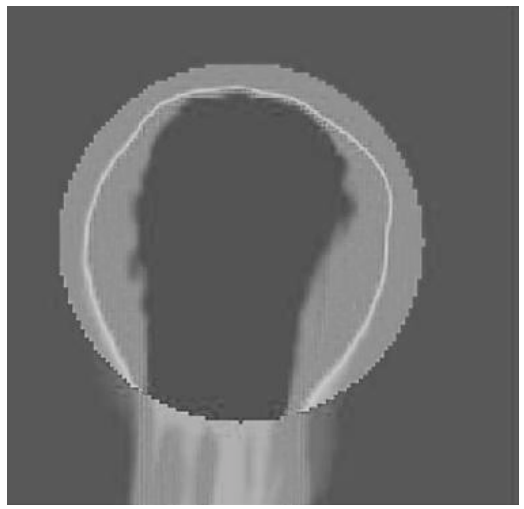

(c) applying elliptical mask correction to remove plume from the image

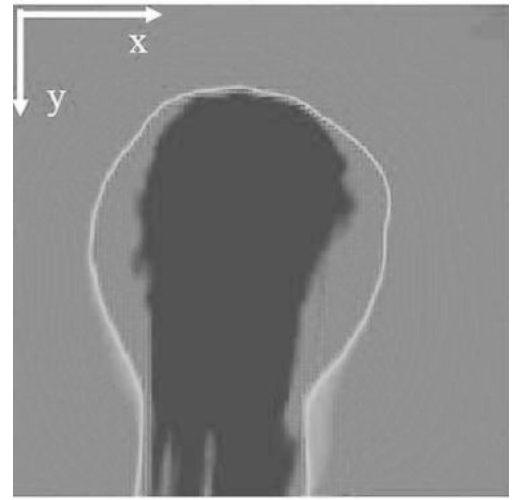

(b) using perspective transform to generate "top view" of the specimen

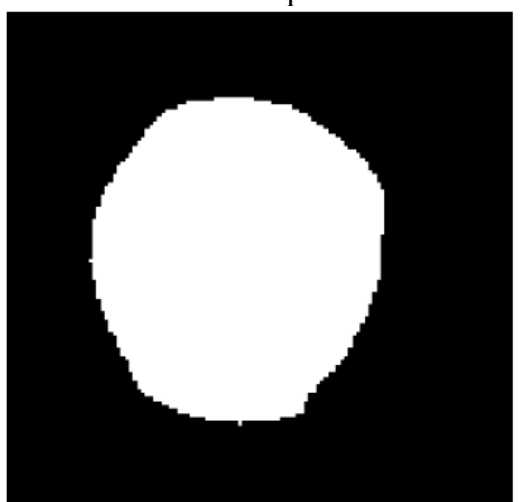

(d) binary image based on $300^{\circ} \mathrm{C}$ threshold used to determine $\mathrm{A}_{\mathrm{f}}(\mathrm{t})$

Fig. 4. Overview of Method Used to Determine Flame Area $A_{f}(t)$ 
Since this flame spread rate measurement procedure was largely automated, results were verified by comparing flame areas with those determined using the previous technique. For eight tests, results obtained using the automated method were compared with flame areas that were estimated by examining frames from the video record and counting the number of $10 \mathrm{~cm}$ by $10 \mathrm{~cm}$ squares that were ignited at $30 \mathrm{~s}$ intervals. It was found that individual flame areas determined using the two different methods were within $150 \mathrm{~cm}^{2}$ of each other, independent of the size of the specimen (i.e., maximum flame areas measured using the two techniques were within $5 \%$ of each other for all eight tests).

It is worth noting that the $2 \mathrm{D}$ spatial transformation used in this method does not correct for distortions native to the camera optics such as spherical aberration. Although this form of distortion is present to some degree in most optics, it was found that the edges of the foam specimens lined up well with the defined coordinate system, indicating that for this experimental apparatus the effect of spherical aberration is negligible relative to the size of the specimen and its placement in the field of view. Another possible source of error in this procedure was the presence of curvature in the specimen surface. Even after being unwrapped and stored flat for a long period of time the specimens still exhibited some curvature and as a result did not sit entirely flat during the experiments. Since this procedure assumes that the top surface of the specimen is a plane, deviation from a flat surface results in some distortion of the "top view" geometry. This distortion was observed in some of the transformed images as an apparent shift in the ignition location of the specimen. This distortion was limited to 2 to $3 \mathrm{~cm}$ and was thus deemed to be negligible.

\section{RESULTS AND DISCUSSION}

A summary of the flame area measurements is shown in Table 3. In this paper, only flame areas measured during the growth phase of the fire are presented. Flame front locations are shown in Fig. 5 for test C4-1 and in Fig. 6 for test E4-1. Examples of the variations between flame areas measured in individual tests within each test series are shown in Fig. 7 (centre ignition) and Fig. 8 and 9 (edge ignition). There was excellent agreement in maximum flame area measurements within a test series, as maximum flame areas corresponded to the entire top surface of the specimen. Variations within a particular test series were largely the result of differences in the dimensions of individual test specimens.

Table 3. Summary of Flame Area Measurements

\begin{tabular}{|c|c|c|c|c|c|c|c|}
\hline \multirow{2}{*}{$\begin{array}{l}\text { Test } \\
\text { Series }\end{array}$} & \multicolumn{3}{|c|}{ Nominal Dimensions } & \multicolumn{2}{|c|}{$\begin{array}{c}\text { Maximum Flame } \\
\text { Area }\left(\mathbf{m}^{2}\right)\end{array}$} & \multicolumn{2}{|c|}{$\begin{array}{c}\text { Time to Reach } 90 \% \text { of } \\
\text { Maximum } \\
\text { Flame Area (s) } \\
\end{array}$} \\
\hline & $\begin{array}{c}\text { Width } \\
\text { (m) }\end{array}$ & $\begin{array}{l}\text { Length } \\
(\mathrm{m})\end{array}$ & $\begin{array}{c}\text { Thickness } \\
\text { (cm) }\end{array}$ & Ave. & $\sigma$ & Ave. & $\sigma$ \\
\hline \multicolumn{8}{|c|}{ Centre Ignition Location } \\
\hline $\mathrm{C} 1$ & 0.6 & 0.5 & 2.5 & 0.330 & 0.003 & 130.0 & 4.78 \\
\hline $\mathrm{C} 2$ & 0.6 & 0.6 & 5.0 & 0.395 & 0.003 & 119.0 & 5.35 \\
\hline $\mathrm{C} 3$ & 0.6 & 0.6 & 7.5 & 0.391 & 0.000 & 104.7 & 2.49 \\
\hline $\mathrm{C} 4$ & 0.6 & 0.6 & 10.0 & 0.379 & 0.005 & 95.7 & 10.87 \\
\hline $\mathrm{CC} 4$ & 1.2 & 1.2 & 10.0 & 1.553 & 0.016 & 131.0 & 4.55 \\
\hline \multicolumn{8}{|c|}{ Edge Ignition Location } \\
\hline E1 & 0.5 & 1.4 & 2.5 & 0.738 & 0.008 & 333.3 & 9.74 \\
\hline E2 & 0.6 & 1.2 & 5.0 & 0.766 & 0.004 & 286.3 & 27.18 \\
\hline E3 & 0.6 & 1.2 & 7.5 & 0.781 & 0.003 & 206.3 & 19.48 \\
\hline $\mathrm{E} 4$ & 0.6 & 1.2 & 10.0 & 0.777 & 0.003 & 190.7 & 11.84 \\
\hline EE4 & 1.2 & 1.2 & 10.0 & 1.524 & 0.019 & 172.0 & 10.71 \\
\hline
\end{tabular}




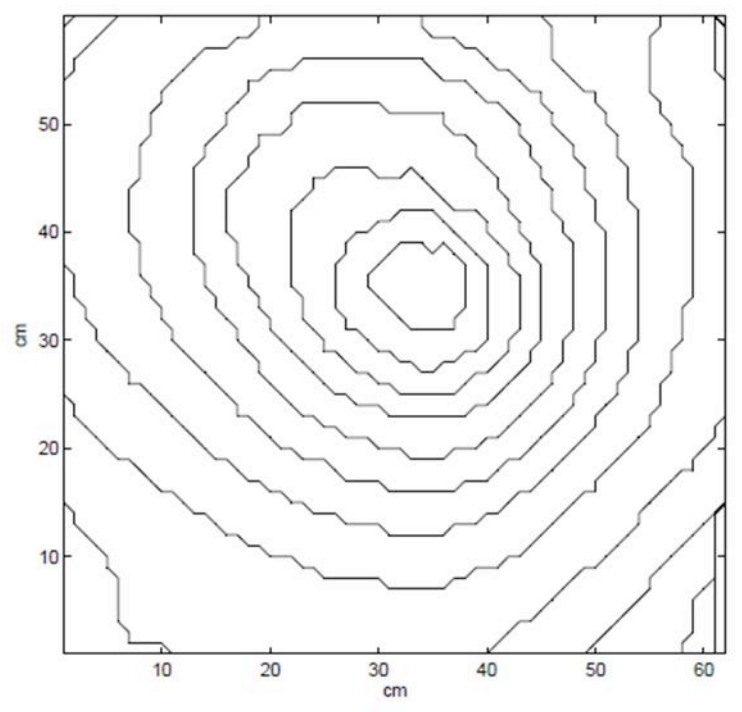

Fig. 5. Flame Front Locations at $10 \mathrm{~s}$ Increments in Test $\mathrm{C} 4-1$

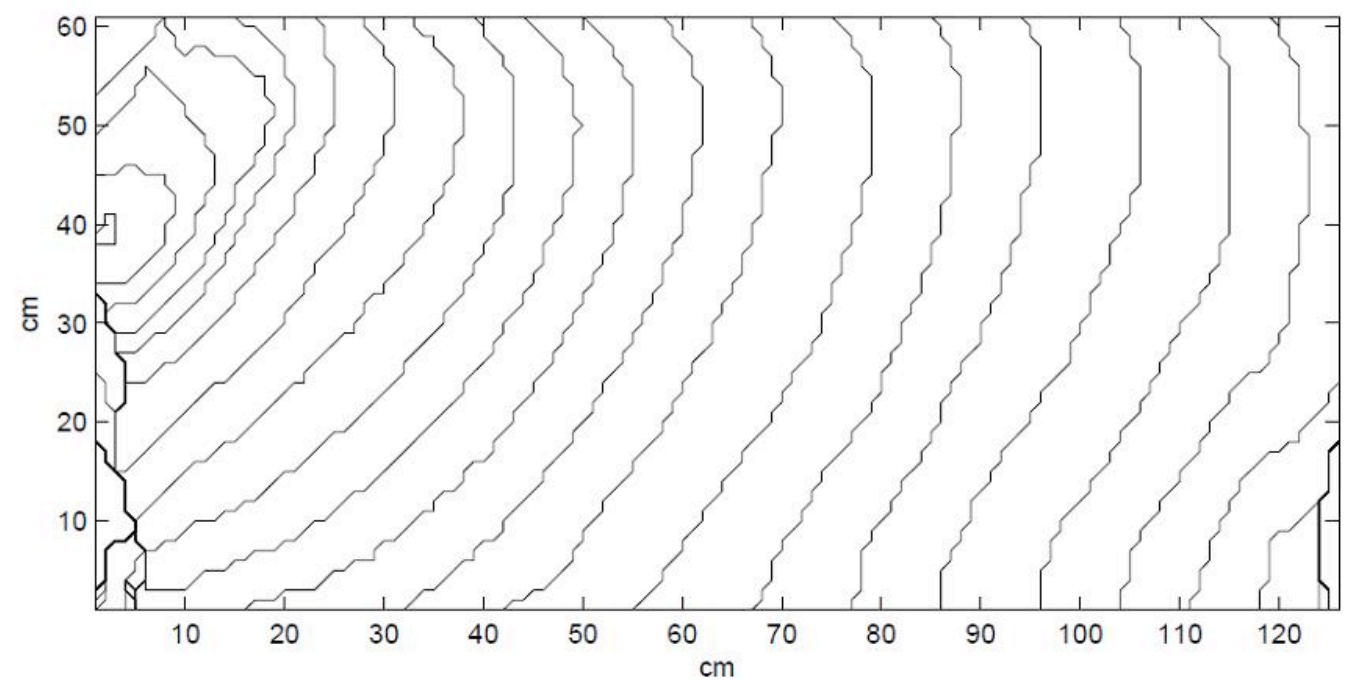

Fig. 6. Flame Front Locations in $10 \mathrm{~s}$ Increments in Test E4-1

While there was sometimes a notable variation in the rate of increase in the flame area with time even for a single test series, in general there was good agreement between the times required to reach $90 \%$ of the maximum flame area, especially for the centre ignition tests. Variations in the time to reach $90 \%$ of the maximum flame area were generally larger for the edge ignition tests; however, in practically all of the tests, standard deviations were much less than $10 \%$ of the average values for that particular test series.

The results indicate that rate of growth of the flame area was affected by environmental conditions during testing. For example, Fig. 7 illustrates that flame area increased more quickly in the less humid test conditions in May (CC4-1, humidity ratio of $0.0045 \mathrm{~kg}$ of water vapour per kg dry air) than in July (CC4-2 and CC4-3, humidity ratio of $0.012 \mathrm{~kg}$ of water vapour per kg dry air). This trend is also shown in Fig. 8 where flame area increased more quickly in tests EE4-1 and EE4-2, which were conducted in May, than in test EE4-3, which was conducted in July. When all of the tests were conducted under similar environmental conditions, there was much less variation in the flame spread rate (e.g., test series E1, which was conducted on the same day (Fig. 9)). Differences in the chemical composition of the individual pieces of foam, and the way in which it expanded after being unwrapped, are also expected to be responsible for minor variations 
in flame spread rates. Lastly, one of the difficulties in comparing furniture calorimeter test data from individual tests lies in establishing the incubation time for each individual test. In this case, the experimental data for the individual tests was adjusted based on the assumption that the incubation time in a given test ended when the heat release rate increased beyond $10 \mathrm{~kW}$.

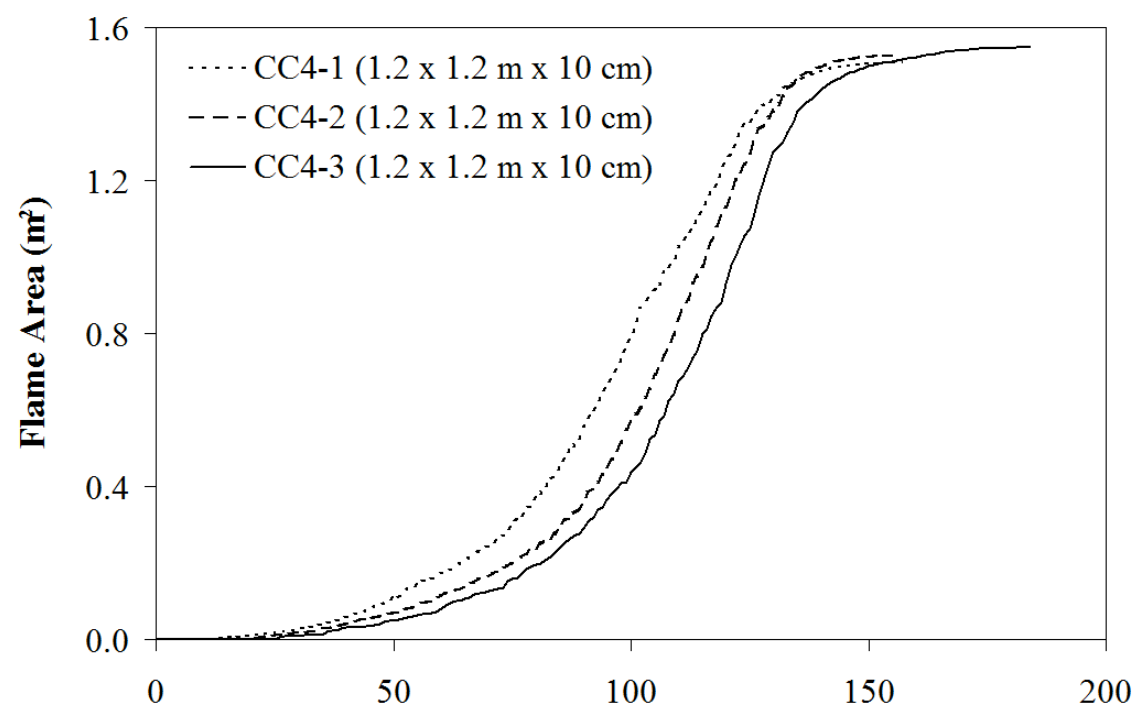

Time (s)

Fig. 7. Flame Areas Measured in Tests of $10 \mathrm{~cm}$ Thick Polyurethane Foam Specimens Ignited at the Centre..

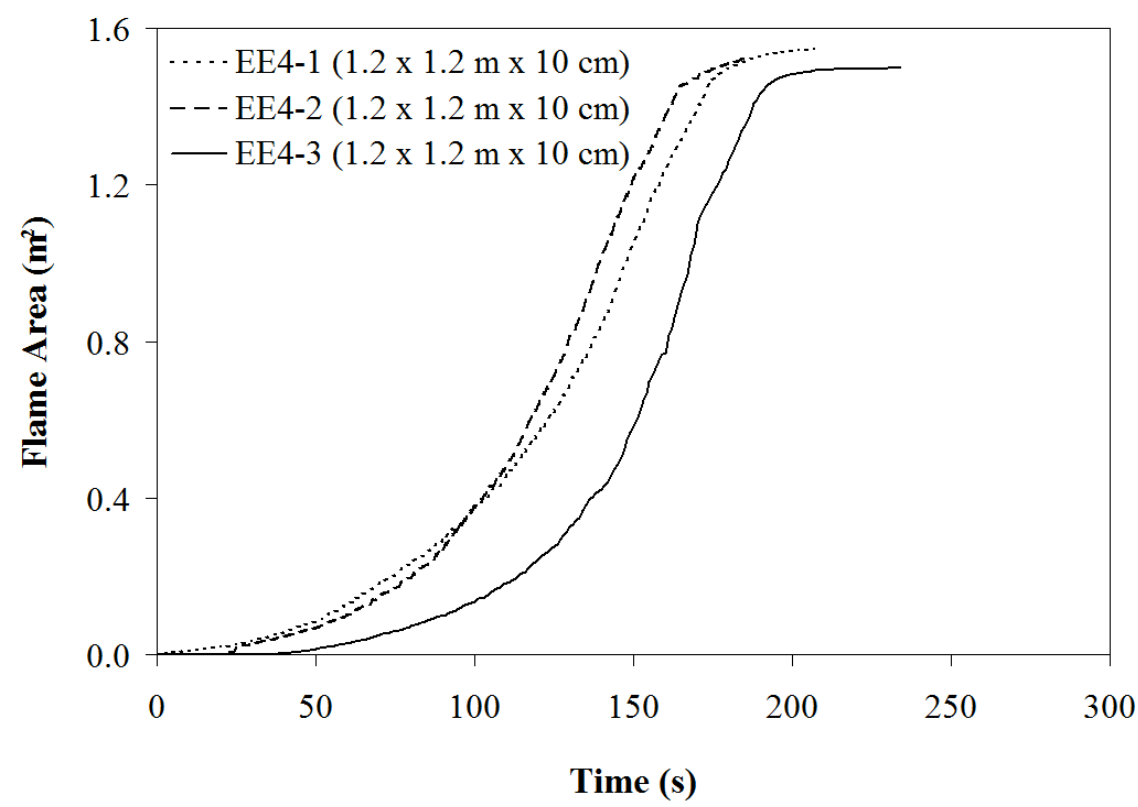

Fig. 8. Flame Areas Measured in Tests of $10 \mathrm{~cm}$ Thick Polyurethane Foam Specimens Ignited on the Edge. 


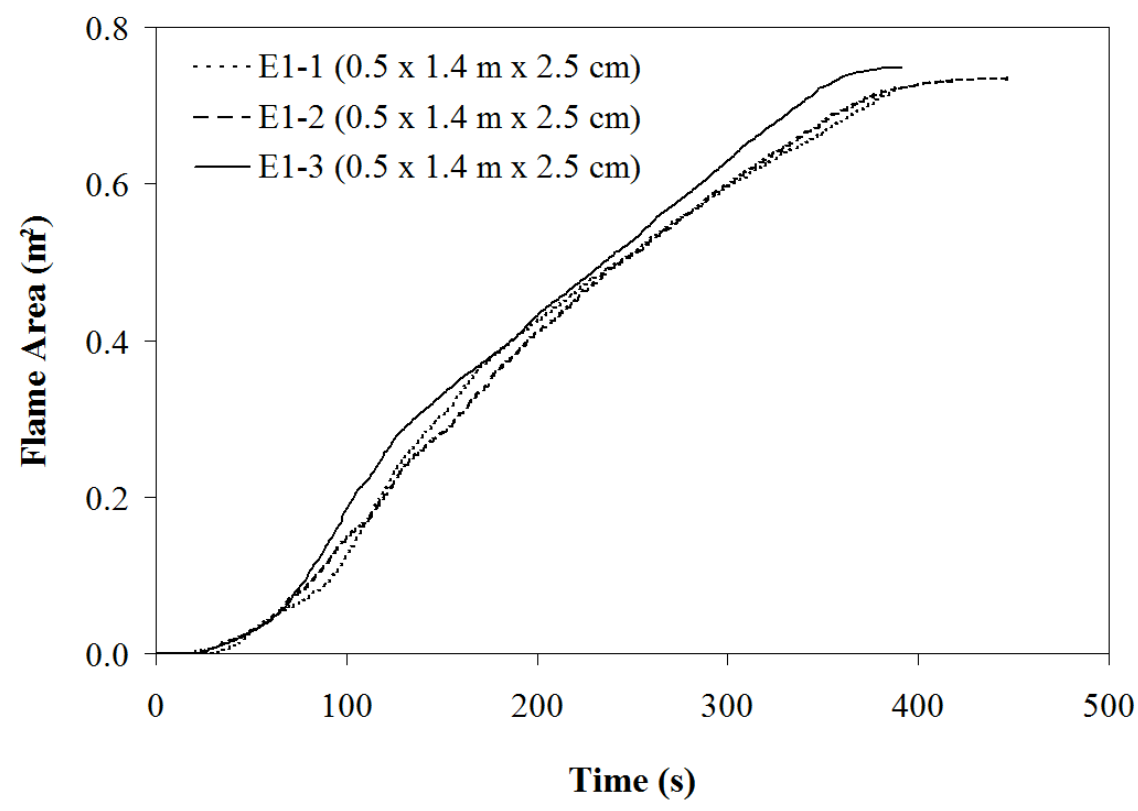

Fig. 9. Flame Areas Measured in Tests of $2.5 \mathrm{~cm}$ Thick Polyurethane Foam Specimens Ignited on the Edge.

Flame areas measured in center and edge ignition tests of foams are shown in Fig. 10 and 11, respectively. Flame area increased more rapidly as foam thickness increased. For specimens ignited at the centre, the time to reach $90 \%$ of the maximum flame area decreased by $8-12 \%$ for each increase in foam thickness of $2.5 \mathrm{~cm}$. The effect was more pronounced for edge ignition tests of the thinner foams, as the time to reach $90 \%$ of the maximum flame area decreased by $15-28 \%$ for each increase in foam thickness of $2.5 \mathrm{~cm}$ up until a thickness of $7.5 \mathrm{~cm}$. A further increase in thickness of $2.5 \mathrm{~cm}$ only resulted in an $8 \%$ decrease in the time to reach $90 \%$ of the maximum flame area.

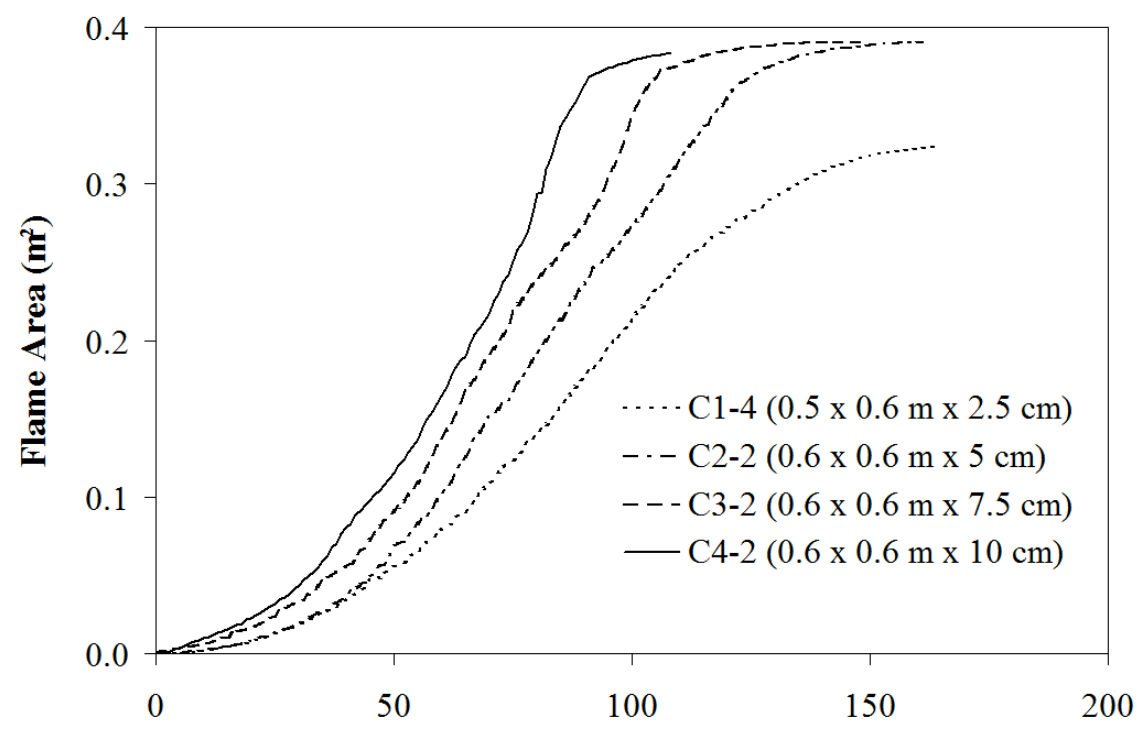

Time (s)

Fig. 10. Flame Areas Measured in Tests of Polyurethane Foam Specimens With Various Thicknesses (as noted in the legend) Ignited at the Centre. 


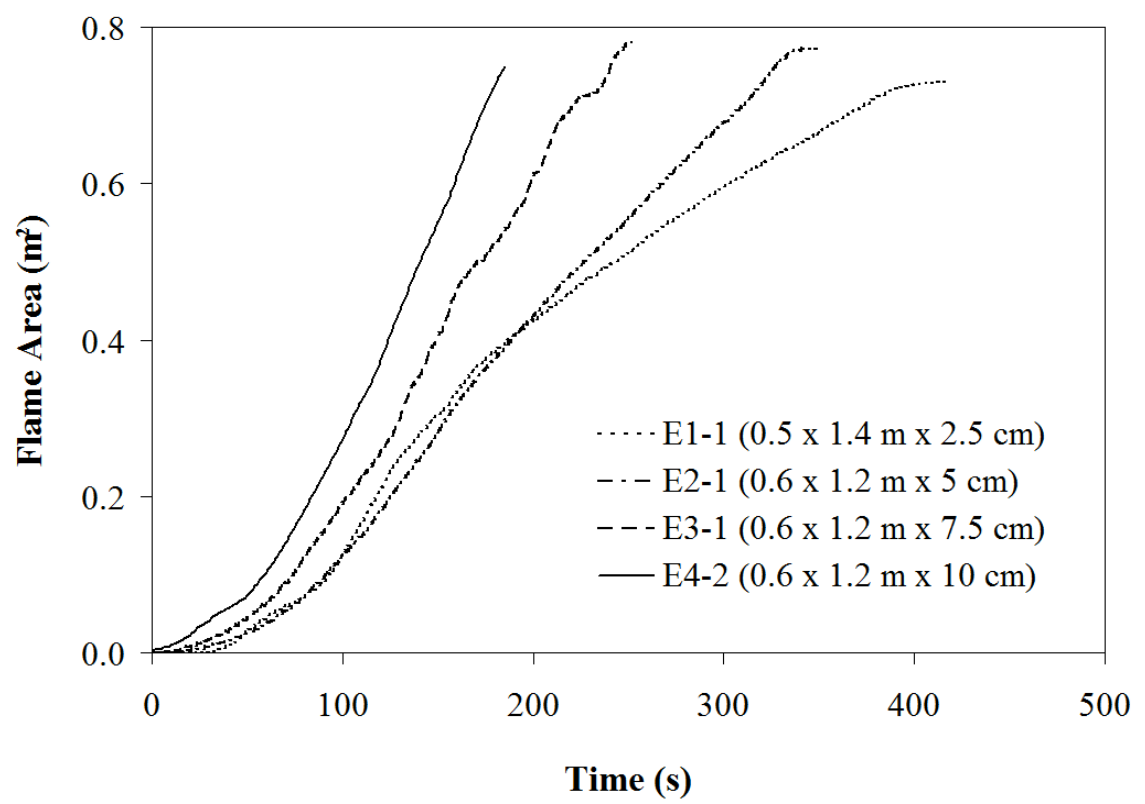

Fig. 11. Flame Areas Measured in Tests of Polyurethane Foam Specimens With Various Thicknesses (as noted in the legend) Ignited on the Edge.

These results can be partially explained in terms of the effects of thickness on heat release rate of each portion of the larger foam sample. To test this theory, cone calorimeter tests of the different thicknesses of foam were also conducted to generate input data for use in Eqn. (1) [13]. The cone calorimeter measurements indicated that average heat release density increases with thickness (Table 4). This increase in heat release rate would result in a larger flame, and an increase in thermal radiation to the foam in front of the flame front, which would increase the flame spread rate.

Table 4. Cone Calorimeter Test Results for Polyurethane Foams Used in This Study [13]

\begin{tabular}{|c|c|c|}
\hline \multirow{2}{*}{$\begin{array}{l}\text { Nominal Foam } \\
\text { Thickness }(\mathrm{cm})\end{array}$} & \multicolumn{2}{|c|}{$\begin{array}{c}\text { Average Heat Release Rate Density } \\
\text { During Burning }\left(\mathrm{kW} / \mathrm{m}^{2}\right)\end{array}$} \\
\hline & Ave. & $\sigma$ \\
\hline 2.5 & 225 & 14.5 \\
\hline 5.0 & 251 & 2.5 \\
\hline 7.5 & 274 & 17.3 \\
\hline 10.0 & 273 & 26.5 \\
\hline
\end{tabular}

The flame area measurement technique presented here did not account for any flames that were established on the sides of the foam. In tests of the thicker foams, this additional area could be significant, as noted in earlier research where this additional area was included in the manual technique for measuring flame area [17]. Thus the present technique only measured flame spread across the top surface of the foam, and not the rate at which the flame moved over the sample in the vertical direction. Heat transfer and subsequent burning in the vertical dimension will be greatly affected by the thickness of the foam as well.

The effects of ignition location on flame spread are shown in Figs. 12 and 13. Flame areas measured in centre and edge ignition tests of the largest foam specimens (surface area of $1.2 \mathrm{~m}$ by $1.2 \mathrm{~m}$ and a thickness of $10 \mathrm{~cm}$ ) are shown in Fig. 12, while an example of flame areas measured in centre and edge ignition tests 
of two of the smaller foam specimens of the same width $(0.6 \mathrm{~m})$ and thickness $(5.0 \mathrm{~cm})$ are shown in Fig. 13. For the larger specimens, flame areas increased at about the same rate for the first $80-90 \mathrm{~s}$ after ignition, and then began to increase more quickly in the centre ignition tests than the edge ignition tests. One reason for this behaviour is that the flames can spread in all directions from a centre ignition point, while they are constrained to move in primarily one direction from the edge ignition point once the flames reach the two sides of the foam. For the smaller specimens, flame spread was more rapid in the centre ignition tests than the edge ignition tests for the entire growth period.

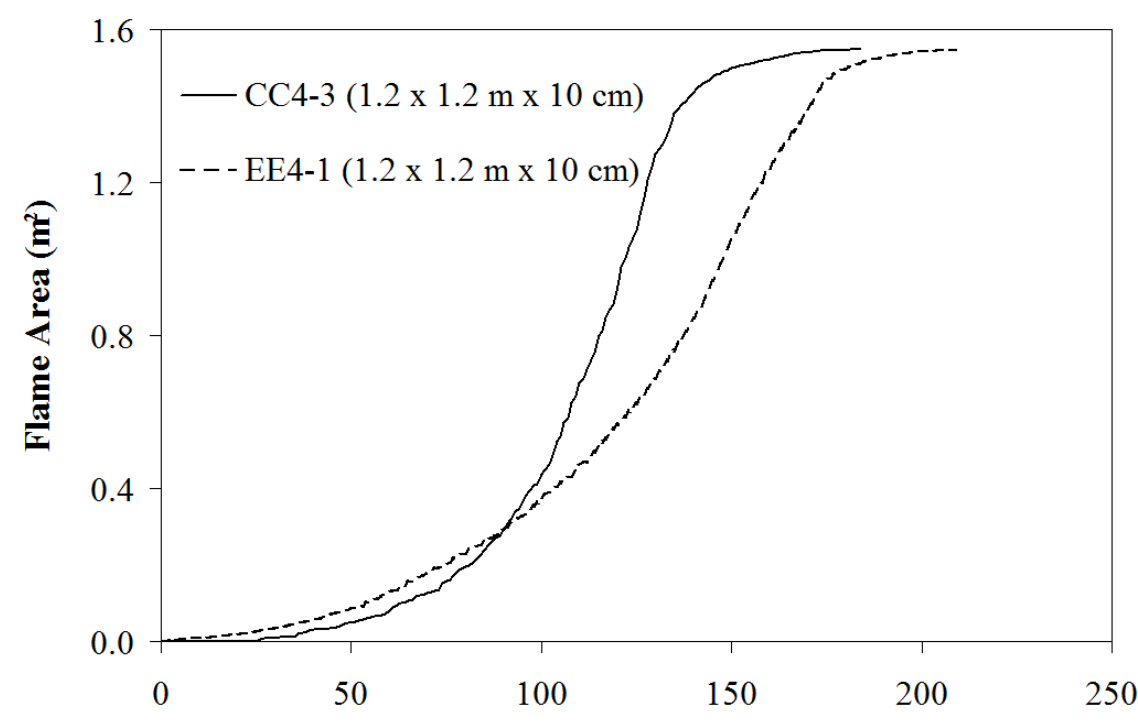

\section{Time (s)}

Fig. 12. Flame Areas Measured in Tests of $10 \mathrm{~cm}$ Thick Polyurethane Foam Specimens, Ignited in the Centre (CC4-3) and on the Edge (EE4-1).

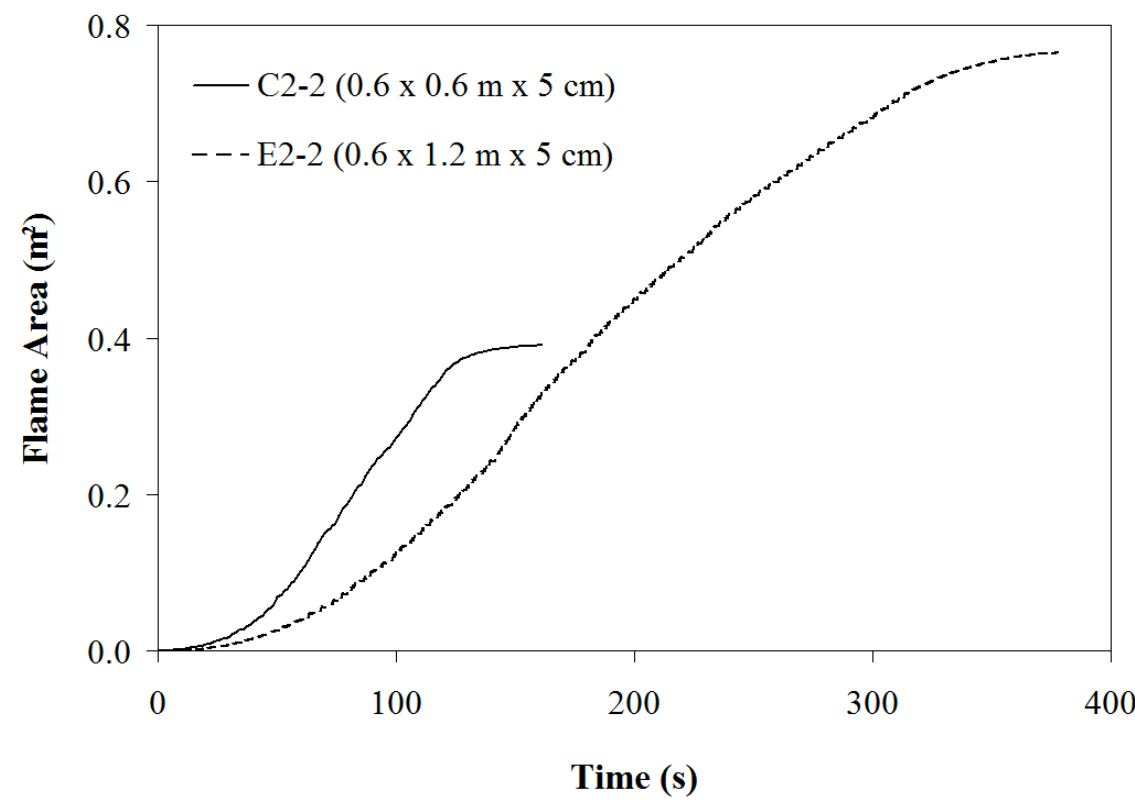

Fig. 13. Flame Areas Measured in Tests of $5 \mathrm{~cm}$ Thick Polyurethane Foam Specimens, Ignited in the Centre (C2-2) and on the Edge (E2-2). 


\section{CONCLUSIONS AND FUTURE WORK}

A method was developed to measure flame spread rates using infrared video records of furniture calorimeter tests of polyurethane foam slabs ranging in thickness from $2.5 \mathrm{~cm}$ to $10.0 \mathrm{~cm}$. Both centre and edge ignition locations were used. This method was an improvement over techniques previously used by the research groups as it allowed measurements to be made more quickly, and in a more objective manner. Flame spread rates increased as foam thickness increased, and flame spread rates were quicker in centre ignition tests than in edge ignition tests.

These flame spread measurements are being used, along with heat release rate density measurements made in the cone calorimeter, to predict the heat release rates measured in the furniture calorimeter tests reported here. If the CBUF model is able to successfully predict heat release rates for these foams, it will then be evaluated for solid-core and inner-spring mattresses and upholstered furniture. As the model currently uses flame spread rates measured in full-scale tests, a flame spread model will also be developed. Two additional phenomena identified in this research that should be considered in a full flame spread model are flame spread along the sides of the specimen, and heat transfer and burning through the foam.

Thus far, the technique reported in this paper has only been used to measure flame spread rates for polyurethane foam specimens; however, it is equally applicable to, and will be used in future, to measure flame spread rates for other materials. It should be noted that the required temperature threshold for the analysis will be material specific, so while a temperature of $300^{\circ} \mathrm{C}$ was found to be suitable for the threshold of the flame front for the polyurethane foam specimens used in this work, it would need to be modified for flame spread measurements for other materials. By way of demonstration of the method, the flame spread was measured across the horizontal surface of the present test specimens, but it should be recognized that measuring flame spread in tests of actual mattresses and upholstered furniture will be more challenging. In inner spring mattresses, once the flames penetrate the fabric layers, they can spread inside the mattress itself. Similarly, flames can spread both horizontally and vertically over the surface of upholstered furniture. Therefore, while the technique reported in this paper will form the basis of flame spread measurements in these more realistic tests, it is expected that modifications will need to be made to address such additional challenges.

\section{ACKNOWLEDGEMENTS}

The authors would like to acknowledge the contributions of Mr. Gord Hitchman, Ms. Janel Rigg, Mr. David Adeosun, Mr. Charles Lin and Mr. Matt DiDomizio from the University of Waterloo Live Fire Research Facility, and Mr. Rick Retzlaff, Mr. Dave Deutscher, Mr. Chris James and Mr. John Ezinwa of the Department of Mechanical Engineering at the University of Saskatchewan. Financial support of this research from the Natural Sciences and Engineering Research Council of Canada (NSERC) and the University of Saskatchewan's Department of Mechanical Engineering and College of Graduate Studies and Research is also gratefully acknowledged.

\section{REFERENCES}

[1] Ahrens, M., "Home Fires That Began With Mattresses and Bedding, National Fire Protection Association, Quincy, MA, 2008, 60 p.

[2] ASTM E 1474, "Standard Test Method for Determining the Heat Release Rate of Upholstered Furniture and Mattress Components or Composites Using a Bench Scale Oxygen Consumption Calorimeter, American Society for Testing and Materials, West Conshohocken, PA, 2010.

[3] CFR 1633, Standard For the Flammability (Open Flame) of Mattress Set, U.S. Consumer Product Safety Commission, Washington, DC, 2006.

[4] CAN/ULC-S137-07, Standard Method of Test for Fire Growth of Mattresses (Open Flame Test), Underwriters Laboratories of Canada, Toronto, ON, 2007.

[5] Sundstrom, B. (ed.), Fire Safety of Upholstered Furniture - the Final Report on the CBUF Research Programme, Interscience Communications, London, UK, 1995. 
[6] Kramer, R.H., Zammarano, M., Linteris, G.T., Gedde, U.W. and Gilman, J.W. (2010) Heat Release and Structural Collapse of Flexible Polyurethane Foam, Polymer Degradation and Stability 95: 1115-1122, http://dx.doi.org/10.1016/j.polymdegradstab.2010.02.019.

[7] Prasad, K., Kramer, R., Marsh, N., Nyden, M., Ohlemiller, T. and Zammarano, M., "Numerical Simulation of Fire Spread on Polyurethane Foam Slabs," Proceedings of the $11^{\text {th }}$ International Fire and Materials Conference, 2009, pp. 697-708.

[8] Butler, K.M., "A Model of Melting and Dripping Thermoplastic Objects in Fire”, Proceedings of the $11^{\text {th }}$ International Fire and Materials Conference, 2009, pp. 341-352.

[9] Saber, H.H., Kashef, A., Bwalya, A.C. and Lougheed, G.D., "Numerical and Experimental Investigation of Fire Behaviour Due to Polyurethane Foam and Wood Cribs in a Medium-Sized Residential Room, National Research Council IRC RR- 291, Ottawa, ON, 2010, 84 p.

[10] Lefebvre, J., Bastin, B., Le Bras, M., Duquesne, S., Ritter, C., Paleja, R. and Poutch, F. (2004) Flame Spread of Flexible Polyurethane Foam: Comprehensive Study, Polymer Testing 23:281290, http://dx.doi.org/10.1016/j.polymertesting.2003.08.003.

[11] Lefebvre, J., Bastin, B., Le Bras, M., Duquesne, S., Paleja, R. and Delobel, R. (2005) Thermal Stability and Fire Properties of Flexible Polyurethane Foam Formulations, Polymer Degradation and Stability 88:28-34, http://dx.doi.org/10.1016/j.polymdegradstab.2004.01.025.

[12] Ezinwa, J., Rigg J., Torvi D. and Weckman, E., "Effects of Ignition Location on Flame Spread and Heat Release Rates in Furniture Calorimeter Tests of Polyurethane Foams," Proceedings of the $11^{\text {th }}$ International Fire and Materials Conference, 2009, pp. 645-656.

[13] Robson, L.D., Obach, M.R., Rigg, J., Ezinwa, J.U., Torvi, D.A. and Weckman, E.J., "Effects of Polyurethane Foam Thickness of Heat Release Rates Measured in Cone and Furniture Calorimeter Tests," Proceedings of the $12^{\text {th }}$ International Fire and Materials Conference, 2011, pp. 309-320.

[14] Hurd, M., Torvi, D., Weckman, E. and Enninful, E., "Effects of Polyurethane Mattress Foam Properties and Geometry on Small and Large-Scale Fire Test Results," Proceedings of the $10^{\text {th }}$ International Fire and Materials Conference, 2007, 13 p.

[15] Ezinwa, J.U., Robson, L.D., Obach, M.R., Torvi, D.A. and Weckman, E.J. (2011) Evaluating Models for Predicting Full-Scale Fire Behaviour of Polyurethane Foam Using Cone Calorimeter Data, Fire Technology, http://dx.doi.org/10.1007/s10694-011-0239-4.

[16] Robson, L.D., "Modeling Full-Scale Fire Test Behaviour of Polyurethane Foams Using Cone Calorimeter Data and Flame Spread Models," M.Sc. Thesis, University of Saskatchewan, Saskatoon, SK, 2013 (in progress).

[17] Ezinwa, J.U., "Modeling Full-Scale Fire Test Behaviour Of Polyurethane Foams Using Cone Calorimeter Data," M.Sc. Thesis, University of Saskatchewan, Saskatoon, SK, 2009.

[18] Wilkie, C.A. and Morgan, A.B. (eds.), Flame Retardancy of Polymeric Materials, Second Edition, Taylor and Francis, Boca Raton, FL, 2010. 